\title{
GENEALOGI ALIRAN-ALIRAN POLITIK DALAM ISLAM
}

\author{
${ }^{1}$ Arif Al Anang, ${ }^{2}$ Ahmad Husein \\ ${ }^{1}$ Universitas Gadjah Mada \\ ${ }^{2}$ Universitas Islam Negeri Sunan Kalijaga \\ ${ }^{1}$ radenarifmasduki@gmail.com, \\ ${ }^{2}$ lubis2925@gmail.com.
}

\begin{abstract}
Abstrak
Tulisan ini akan mendiskuisikan tentang banyaknya aliran pemikiran yang diwarisi generasi umat Islam. Islam akan menjadi lemah disebabkan banyaknya aliran yang melahirkan perpecahan dan menjadi dampak negatif bagi Islam sendiri. Setelahnya wafatnya Nabi para sahabat merumuskan siapa yang akan mengantikan kekhalifahan (pemimpin) dalam Islam Sehingga memakamkan Nabi tertunda selama dua hari. Terpilihlah khalifah yang pertama Abu Bakar yang kedua Umar bin Khattab, ketiga Usman bin Affan dan yang keempat Ali bin Abi Thalib. Penelitian yang ada di hadapan pembaca ini menggunakan metode sejarah dengan pendekatan kualitatif deskriptif. Kemunculan Aliran-aliran politik dalam Islam disebabkan kebijakan Ali bin Abi Thalib yang menyetujui attahkim (arbitrase) antara pasukan Ali dan Muawiyah, sehingga sebahagian pasukan Ali kecewa karena kebijakan tersebut dan menjadi perpecahan ummat Islam.
\end{abstract}

Kata Kunci: politik, penyebab perpecahan, aliran-aliran politik

\begin{abstract}
This paper will discus about the many schools of thought inherited from generations of Muslims. Islam will become weak due to the many sects that create divisions and have a negative impact on Islam itself. After the death of the Prophet the companions formulated who would replace the caliphate (leader) in Islam. So that the burial of the Prophet was delayed for two days. The first caliph was chosen, Abu Bakr, the second, Umar bin Khattab, the third was Usman bin Affan and the fourth was Ali bin Abi Talib. The research that is in front of the reader uses historical methods with a descriptive qualitative approach. The emergence of political schools in Islam was due to Ali bin Abi Talib's policy of agreeing to attahkim (arbitration) between Ali and Muawiyah's troops, so that some of Ali's troops were disappointed by this policy and it became a division of the Muslim community.
\end{abstract}

Keywords: politics, causes of division, political sects

\section{PENDAHULUAN}

Tulisan ini mendiskuisikan tentang banyaknya aliran pemikiran yang diwarisi generasi umat Islam sampai sekarang baik aliran politik maupun teologis. Sebelum Islam masuk ke kota Mekah, bangsa Arab terdiri dari suku-suku, salah satunya adalah suku Quraisy yang memiliki kedudukan terhormat diantara suku-suku lainnya karena mereka suku yang menjadi pewaris dari nabi Ibrahim dan Ismail bahkan kemuliaan dapat diwariskan dari keturunan 
tertentu (Abidin 2006). Setelah nabi hijrah ke Madinah dalam waktu yang bersamaan Nabi memegang dua jabatan yaitu pemimpin politik dan dan pemimpin agama. Nabi juga berhasil mendirikan sebuah negara yang dikenal dengan Negara Madinah (Fadli 2018).

Tema politik masih menjadi isu yang menarik dibicarakan pada saat ini apalagi politik Islam (Fadli 2018). Secara etimologi politik alam bahasa arabnya disebut "siyasah" atau dalam bahasa Inggrisnya "politics". Politik itu sendiri berarti cerdik dan bijaksana. Memang dalam pembicaraan sehari-hari kita seakan-akan mengartikan politik sebagai suatu cara yang dipakai untuk mewujudkan tujuan, tetapi sebenarnya para ahli ilmu politik sendiri mengakui bahwa sangat sulit memberikan definisi tentang ilmu politik (Syafiie 1996). Politik secara etimologi adalah pemerintahan, pengambil keputusan, pembuat kebijakan dll. Sedangkan makna istilah, Fiqh siyasah diartikan sebagai berikut, Menurut Ahmad Fathi Pengurusan kemaslahatan umat manusia sesuai dengan ketentuan syara (Djazuli 2003).

Sesudah Nabi wafat masalah yang pertama sekali muncul adalah kekosongan pemimpin politik, Nabi tidak meninggalkan pesan dengan jelas dan tegas siapa yang akan menggantikannya. Sebelum Nabi di makamkan para sahabat berkumpul di Saqifah Bani Sa'idah merumuskan untuk menjadi pemimpin Negara antara kalangan Anshor dan Muhajirin, pada akhirnya terpilih Abu Bakar sebagai pengganti Nabi. Penunjukan Abu bakar sebagai pengganti Nabi tidak dibenarkan dari kalangan Keluarga Nabi (Ahlu bayt). Bahwa kepemimpinan sudah di tetapkan oleh Nabi Muhammad sebelum wafatnya yakni Ali Bin Abi Thalib dengan mengambil dalil dari hadis Nabi (man kuntu maulahu fa'aliyyu maulahu). Ahli Bayt gagal menaikkan Ali menjadi pemimpin kekuasaan sementara yang naik menjadi pemimpin adalah Abu Bakar ini melahirkan perpecahan politik yang serius di internal umat Islam (Fadli 2018). Selanjutnya penulis mengemukakan mengapa aliran-aliran politik dalam islam muncul dan aliran apa saja yang ada di dalamnya?

\section{METODE PENELITIAN}

Penelitian menggunakan metode sejarah, karena itu secara metodologis proses yang dilakukan melalui tahapan heuristik, kritik, interpretasi, dan historiografi (Herlina 2020). Data didapatkan penelitian didapatkan dari kajian pustaka dari berbagai sumber buku yang menjelaskan tentang sejarah panjang politik Islam sejak wafanya Nabi Muhammad SAW. Data tersebut merupakan data sejarah berupa fakta yang memiliki arti lebih bermakna daripada sekedar sajian angka atau frekuensi, Pendekatan yang digunakan dalam penelitian ini adalah deskriptif yaitu, penelitian yang menyajikan temuan dalam bentuk deskriptif 
kalimat yang rinci, lengkap, dan mendalam yang menggambarkan hasil penelitian secara analitis.

\section{HASIL DAN PEMBAHASAN}

\section{A. Lahirnya Aliran Politik dalam Islam}

Munculnya pemikiran politik Islam diawali pada masa Rasulullah sejak mendirikan komunitas Islam di sekitaran Madinah pada tahun $622 \mathrm{M}$. pada masa tersebut terbilang sebagai awal kebangkita umat Muslim mampu berinteraksi dengan suku-suku di luar Islam. System pemikiran ini berlangsung hingga Rasalullah wafat dan dilanjutkan pada generasi sahabat-sahabatnya (khulafa' rosyidun) hingga puncaknya dinasti Umayyah dan Abbasiyah. Pasca wafatnya Rasulullah, terjadi saling merebutkan kekuasaan antara satu kelompok dengan yang lain. Menurut Phillip K Hitti, pasca wafatnya Nabi Muhammad saw yaitu (1) Kelompok Muhajirin dan Ansar (disebut kelompok sahabah) dengan argumentasi masing masing, (2) Kelompok legitimis (Ashab an nash wa ta'yin) yang meyakini bahwa Nabi Muhammad saw menunjuk Ali Ibn Abi talib sebagai penggantinya, dan (3) Kelompok aristokrat Qurays yang dimotori oleh Bani Umayyah. Akhirnya kelompok pertamalah yang berhasil menduduki kekhalifahan, yaitu dengan terpilihnya Abu bakar as Shiddiq (Hitti 2005).

Abu Bakar as Siddiq berhasil menjadi khalifah pertama yang berkuasa selama dua tahun (11-13H/632-634M). Keterpilihan Abu Bakar melewati proses musyawarah yang alot, antara kelompok Muhajirin dan Ansar. Majelis Tsaqifah Bani Sa'adah menjadi saksi atas perdebatan para sahabat senior tentang sistem politik yang akan dijalankan. Perdebatan ini dipicu oleh dua hal. Pertama, tidak adanya kejelasan sistem politik dari Rasulullah sebagai pemegang otoritas keagamaan. Kedua, persaingan kelompok sosial antara Muhajirin dan Ansar yang merasa memiliki hak yang sama atas kepemimpinan umat Islam. Akhir drama politik di Tsaqifah Bani Sa'adah adalah disetujuinya Abu Bakar sebagai khalifah oleh mayoritas umat islam pada saat itu. Alasan pemilihan Abu Bakar adalah aspek senioritas, loyalitas, dan kapabilitas. Abu Bakar termasuk kelompok as Sabiqun al Awwalun, loyal kepada Rasulullah dalam mendampingi dakwahnya, dan memiliki kemampuan intelektual yang tinggi dalam masalah keislaman. Setelah abu Bakar Wafat yang menggantikan khalifah adalah Umar Ibn Khattab, Umar memerintah selama 10 tahun (13-23H/634-644M). Penunjukan Umar sebagai khalifah adalah adalah hasil dari keputusan muswarah para sahabat senior di Madinah dan ini tidak bisa dinggap sebagai otoritarianisme Abu Bakar. 
Umar yang ditunjuk sebagai khalifah untuk menghindari perpecahan dikangan internal Islam itu sendiri.

Awal mula timbulnya aliran politik pada masa khalifah Ustman bin Affan (setelah wafatnya), pada masa itu dilatarbelakangi kepentingan kelompok yang melahirkan perselisihan hingga terbunuh Khalifah Ustman. Kemudian, khalifah di gantikan Ali bin Abu Thalib dan perpecahan terus berlanjut. Islam yang mengikuti Ali bin Abu Thalib menamakan dirinya dengan Syi'ah sementara yang kontra dengan Ali bin Abu Thalib menyebutkan dirinya dengan khawarij. Perpecahan dikalangan umat Islam memuncak kemudian terjadilah peperangan diantara Ali bin Abu Thalib dan Aisyag (perang Jamal), dan peperangan Ali bin Abu Thalib dengan Muawiyah (Shiffin) (Rozak and Anwar 2001).

Menurut Abid Al-Jabiri, jauh sebelum persoalan politik tersebut mengemuka, telah terbangun kerangka pemikiran yang memungkinkan terjadinya variasi kelompok politik dan pemikiran di kalangan umat islam. Situasi krisis politik pasca nabi, hanyalah sebuah momentum yang memantik munculnya perbedaan tersebut, benih dan kerangkanya sudah tersedia sebelumnya. Asumsi Al-Jabiri tersebut bisa dibuktikan bila melihat dinamika aliran teologi dalam islam pada rentang waktu kemudian, baik syiah maupun sunni yang terus berkembang dari periode ke periode tidak lagi berbentuk sebagai aliran politik an sich, tetapi juga aliran pemikiran yang memiliki corak dan identitas yang berbeda, antara satu sama lainnya. Kalau hanya persoalan politik, pasti keberlangsungannya hanya sementara, hanya sebatas perebutan kepentingan politik. Namun, karena yang memicu munculnya aliran tersebut adalah kerangka pemikiran (paradigma), maka aliran tersebut pun abadi, melampaui konteks krisis politik di Arab pasca kepemimpinan nabi Muhammad SAW (Abidin 2012).

\section{B. Aliran-aliran Politik dalam Islam}

\section{Sunni}

Sunni dikenal juga dengan istilah Ahli Sunnah Waljamaah adalah satu aliran yang mengklaim mengikuti Sunnah aliran yang mengikuti Rasul dan Para sahabat. Secara sederhana dapat dikatakan bahwa paham Sunni adalah paham yang berpegang teguh pada tradisi salah satu mazhab dari mazhab yang empat (Hanafi, Maliki, Syafìi dan Hanbali) dalam bidang fikih; ajaranAbu al-Hasan al-Asy`ari dan Abu Manshur al-Maturidi dalam bidang teologi; ajaran al-Junaid dan al-Ghazali dalam bidang tasawuf (Dhofier 1994)), serta ajaran/pemikiran kelompok mayoritas ulama seperti al- Mawardi, al-Ghazali serta Ibn Taimiyah dalam bidang politik (siyasah). Istilah Sunni dikenal pemakaiannya dalam konteks 
politik dan untuk membedakannya dengan kelompok-kelompok politik lain seperti Khawarij dan Syieeah.

Sejarah Sunni dimulai ketika ricuhnya perpolitikan yang mengatasnamakan Islam. Nabi Muhammad wafat sebelum menunjuk pengganti. Oleh karena itu, terjadi konflik tentang siapa yang paling pantas menggantikan beliau sebagai khalifah. Setelah ketegangan dan tarik-ulur selama dua hari sehingga menunda pemakaman jasad Nabi Muhammad, ditunjuklah Abu Bakar as-Shiddiq sebagai khalifah. Penunjukan ini tidak memuaskan beberapa kalangan. Bahkan, kalangan yang mengklaim bahwa Ali bin Abi Thalib lebih sah menjadi khalifah kemudian memisahkan diri dan membentuk Syiah (Abdullah et al. 2005). Sementara itu, golongan yang lebih umum, kemudian disebut Sunni. Golongan ini hingga saat ini terbagi dalam empat mazhab berbeda. dalam kelompok ini yang perlu dicatat, empat mazhab tersebut tidak menandakan perpecahan. Perbedaan empat mahzab hanya terletak pada masalah-masalah yang bersifat abu- abu, tidak diterangkan secara jelas oleh Al-Quran atau hadits seiring dengan kemajuan zaman dan kompleksitas hidup muslim (Abdullah et al. 2005).

Kemudian dari pada itu, dalam peta politik Islam, Sunni adalah kelompok mayoritas yang selalu memegang supremasi kekuasaan. Pemikiran politik Sunni sering dijadikan sebagai alat legitimasi bagi kekuasaan yang sedang berkembang di dunia Islam. Beberapa tokoh Sunni merumuskan pemikiran politik mereka yang cenderung bersifat akomodatif terhadap kekuasaan dan pro pada status quo. Pandangan mereka yang bersifat khalifah sentris adalah ciri umum paradigma politik Sunni. Kepala negara atau khalifah memegang peranan penting dan memiliki kekuasaan yang sangat luas. Rakyat dituntut untuk mematuhi kepala negara, bahkan di kalangan sebagian pemikir Sunni kadang-kadang sangat berlebihan. Biasanya mereka mencari dasar legitimasi keistimewaan kepala negara atas rakyatnya pada Al-Quran dan Hadis Nabi Saw (Al Anang 2019). Di antaranya yang mereka jadikan landasan adalah surat al-Nisa, 4:59 yang memerintahkan umat Islam untuk patuh kepada Allah, RasulNya dan ulu al-amr di antara mereka. Selain itu juga surat al- An`am, 6:165 yang menyatakan bahwa Allah menjadikan manusia sebagai khalifah- Nya di bumi dan melebihkan sebagian atas yang lain.

Keberadaan kelompok Sunni dimulai sejak berakhirnya pemerintahan al- Khulafa`alRasyidun. Selain dinamakan Sunni, kelompok ini juga dikenal dengan nama ahl al-hadis wa al-sunnah, ahl al-haqq wa al-sunnah dan ahl al-haqq wa al-din wa al-jama`ah (Nasution 1986). Setelah Nabi SAW wafat terjadi perdebatan di kalangan umat Islam tentang siapa 
yang akan menggantikan beliau sebagai pemimpin umat Islam. Sebelum wafat Nabi tidak memilih dan menunjuk tentang siapa penggantinya kelak. Akhirnya, dalam sebuah pertemuan di Saqifah Bani Sa`idah, terpilihlah Abu Bakar sebagai pengganti Nabi. Setelah itu berturut-turut terpilih Umar ibn al-Khattab, Usman ibn Affan dan Ali ibn Abi Thalib sebagai pemimpin umat Islam. Mereka kemudian dikenal sebagai Khulafa al-Rasyidin. Setelah berakhir masa khalifah yang empat tersebut, naiklah Mu`awiyah yang membangun Dinasti Bani Umaiyah. Namun naiknya Mu`awiyah mendapat tantangan dari sebagian umat Islam yang mendukung Ali (Syi`ah) dan kelompok sempalan Khawarij. Akhirnya pada periode awal umat Islam terpecah menjadi tiga kelompok, yaitu mayoritas pendukung Mu`awiyah yang kemudian dikenal dengan jamaah (Sunni), pendukung Ali (Syi ah) dan Khawarij. Dalam perkembangan selanjutnya, kelompok Sunnilah yang paling mendominasi percturan politik Islam (Dhofier 1994).

\section{Syiah}

Syi`ah secara etimologi berarti pengikut, pendukung, pembela, pencinta, yang kesemuanya mengarah kepada makna dukungan kepada ide atau individu dan kelompok tertentu (Syihab, 2007). Ajaran Syiah berawal pada sebutan yang untuk pertama kalinya ditujukan kepada para pengikut Ali (Syiat Ali), pemimpin pertama Ahlul Bait pada masa hidup Nabi (Thabaththaba'i, 1989). Syiah dalam Bahasa Arab dan Bahasa Persia ialah salah satu aliran atau mazhab dalam Islam. Syiah menolak kepemimpinan dari tiga Khalifah Sunni pertama seperti juga Sunni menolak Imam dari Imam Syiah. Bentuk tunggal dari Syiah adalah Syi'i (Bahasa Arab) menunjuk kepada pengikut dari Ahli Bayt dan Imam Ali (AlNemr 1988).

Ibnu Khaldun, yang berkata, "Syiah muncul ketika Rasulullah saw wafat. Saat itu Ahli Bayt memandang dirinya lebih berhak memimpin umat Islam. Kekhalifahan hanyalah hak mereka bukan untuk orang Quraisy yang lain. Saat itu pula sekelompok sahabat Nabi saw mendukung Ali ibn Abi Thalib dan memandangnya lebih berhak ketimbang yang lain untuk menjadi pemimpin. Namun, ketika kepemimpinan itu beralih kepada selain Ali, mereka pun mengeluhkan kejadian itu (Dewi 2016). Pendapat yang lain, Golongan syiah muncul pada akhir masa khalifah ketiga, Utsman kemudian tumbuh dan berkembang pada masa khalifah Ali bin Abi Thalib. Ali bin Abi Thalib sendiri tidak berusaha untuk mengembangkannya, tetapi bakat-bakat yang dimiliknya telah mendorong perkembangan itu. Ketika Ali bin Abi Thalib wafat, pemikiran kesyiahan berkembang menjadi mazhab-mazhab. Sebagianya 
menyimpang sebagiannya lurus. Namun, keduanya sama-sama fanatik terhadap keluarga Nabi (Zahrah 1996).

Kemudian paham Syi'ah dibawa oleh seorang pendeta Yahudi dari Yaman yang memeluk agama Islam bernama Abdullah ibn Saba. Ia telah menaburkan fitnah, supaya rakyat membenci khalifah Utsman dengan mengatakan bahwa Ali bin Abi Thalib lebih berhak menjadi khalifah. Menurutnya Rasulullah saw pernah berwasiat supaya Ali ibn Abi Thalib menjadi khalifah sesudah beliau wafat. Paham ini telah tersebar di kota-kota yang akhirnya membawa kepada pembunuh Utsman. Setelah wafat Utsman, maka dilantiklah Ali ibn Abi Thalib sebagai khalifah ke-4 tahun 35H. Hal ini tidak memuaskan sebagian umat Islam saat itu, sehingga terjadilah perang saudara antar Ali ibn Abi Thalib dan Aisyah (istri Rasulullah) pada tahun $36 \mathrm{H}$, yang dikenal dengan perang Jamal (unta) karena, Aisyah yang mengepalai tentaranya dengan menunggang unta (Zamzami 2007).

Syi'ah adalah mazhab politik yang pertama lahir dalam islam, mazhab ini lahir akhir pada masa pemerintahan ustman, kemudian tumbuh dan berkembang pada masa Ali ibn Abi Thalib, setiap kali ia berhubungan dengan masyarakat, mereka semakin mengagumi bakat, keutamaan beragama, dan ilmunya. Karena itu, para propagandis syiah mereka mengeksploitasi kekaguman mereka terhadap Ali ibn Abi Thalib untuk menyebarkan pemikiran pemikiran mereka tentang dirinya, di antara pemikiran itu ada yang menyimpang ada juga yang lurus. Ketika keturunan Ali bin Abi Thalib sekaligus keturunan rasullah mendapat perlakuan zalim dan penyiksaan pada masa Umayyah, rasa cinta mereka terhadap keturunan Ali bin Abi Thalib semakin mendalam. Mereka memandang ahli bait ini Syuhada dan korban kezaliman. Dengan demikian, meluaslah Mazhab Syi'ah dan mendukungnya semakin banyak (Rozak and Anwar 2001).

Orang-orang sepakat bahwa Ali ibn Abi Thalib adalah khalifah pilihan Nabi Muhammad dan ia adalah orang yang paling utama (afdhal) di antara para sahabat Nabi. Tampaknya di antara para sahabat sendiri ada orang-orang yang sependapat dengan syi'ah tentang keutamaan ali atas sahabat Nabi yang lain. bin Abi al-Hadid, seorang syi ec $^{\text {i moderat }}$ menyebutkan bahwa di antara sahabat yang mengutamakan Ali bin Abi Thalib atas sahabat lainnya ialah; Ammar bin Yasir al-Miqdad bin al-Aswad, Abu Dzar al-Ghifari, Salman alFarisi, Jabir ibn Abdullah, Ubay ibn Ka'ab, Hudzaifah, Buraidah, Abu Ayyub al-Ansyari, dll. Pada mulanya Ibn al-Zubeir termasuk orang yang berpendapat demikian, tetapi kemudian meralatnya. Dia juga mengatakan sebagian bani Umayyah sependapat dengan pandangan itu di antara mereka adalah Sa'id ibn al-Ash. Orang- orang syi'ah tidak bersikap sama dalam 
menetapkan posisi ali dan keturunannya, sebagian bersikap ekstrim dan sebagian lain bersikap moderat.

Doktrin merupakan bagain tidak terpisahkan dari sebuah ideologi, karena itu Syiah juga memiliki doktrin. Secara lebih rinci doktrin-doktrin Syi'ah tersebut yaitu; a) Mereka berpendapat bahwa masalah kepemimpinan negara bukan permasalahan kemaslahatan umum yang diserahkan kepada masyarakat muslim, orang-orang yang mempunyai hak untuk memimpin masyarakat muslim telah ditunjuk dan ditentukan langsung oleh Allah SWT (Zahrah 2005); b) Imam Ali ibn Abi Thalib r.a adalah pemimpin yang ditunjuk oleh Rasulullah saw untuk menjadi khalifah setelahnya; c) Tauhid. Tuhan adalah Esa baik esensinya maupun eksistensi-Nya, keesaan Tuhan adalah mutlak dan qadim; d) Keadilan. Tuhan menciptakan kebaikan di alam semesta ini merupakan keadilan, Ia tidak pernah menghiasi ciptaannya dengan ketidakadilan; e) Nubuwwah, setiap makhluk sekalipun telah diberi insting, masih membutuhkan petunjuk, baik petunjuk dari Tuhan maupun dari manusia; dan f) Ma'ad adalah hari kiamat, untuk menghadapi pengadilan Tuhan di akhirat.

Aliran-aliran Syi'ah juga telah tumbuh dan berkembang. Penganut syi'ah terdiri atas kelompok yang ekstrim al-gulat, moderat dan liberal. Di antara kelompok yang ekstrim ada yang menempatkan Ali ibn Abi Thalib pada derajat ketuhanan, ada yang mengangkatnya kepada derajat kenabian, bahkan lebih tinggi dari Muhammad. Di antara aliran-aliran itu, ialah: Saba"iyyah, Ghuhrabiyyah, Kaisaniyyah, Zaidiyyah, Imamiyyah Itsna'Asyariyyah (Imamiyah Dua Belas), Ismailiyyah, Hakimiyyah dan Druz, Nashiriyyah.

\section{Khawarij}

Khawarij adalah aliran yang keluar dari barisan Ali bin Abi Thalib kemudian, asySyahrastani berpendapat Khawarij adalah orang yang berpaling atau keluar dari pemimpin yang sah secara konstitusional baik dalam pemerintahan Khulafa ar-Rasyidin atau pemerintahan tabi'in (Purnama 2016). Mazhab khawarij muncul bersamaan dengan mazhab Syi'ah, masing-masing muncul sebagai sebuah mazhab pada masa pemerintahan khalifah Ali ibn Abi Thalib. Pada awalnya, pengikut kedua mazhab ini adalah para pendukung Ali bin Abi Thalib, meskipun pemikiran mazhab khawarij lebih dahulu muncul daripada mazhab Syi'ah. Untuk mengidentifikasi sekte Khawarij, baik sebagai gerakan politik maupun kerangka doktrinalnya, kekisruhan politik kekuasaan yang terjadi pada masa kekhalifahan Ali ibn Abi Thalib, atau dikenal peristiwa al-fitnah al-kubra, penting untuk dijadikan titik-tolak.

Dalam hal ini, Ali ibn Abi Thalib mewarisi dua persoalan krusial di awal pemerintahannya menggantikan Usman ibn Affan. Keduanya bahkan telah memicu peristiwa perang saudara yang 
terjadi di bukit Jamal dan Shiffin (Purnama 2016). Pertama, persoalan suksesi khalifah setelah wafatnya Usman ibn Affan. Baiat terhadap Ali ibn Abi Thalib mendapatkan penolakan dari Talhah ibn Ubaidillah dan Zubair ibn al-Awwam yang mendapat dukungan politik dari Aisyah, karena menganggap suksesi kekhalifahan lebih berhak diberikan kepada Talhah. Persoalan ini dapat diselesaikan, Ali ibn Abi Thalib setelah perang Jamal yang terjadi di Irak pada tahun 656 M. Talhah dan Zubair terbunuh dalam peperangan tersebut, sedangka Aisyah dipulangkan kembali ke Makkah (Nasution 1972). Kedua, persoalan keengganan Muawiyah ibn Abi Sufyan untuk membaiat Ali ibn Abi Thalib dan tuntutannya untuk segera menyelesaikan permasalahan terbunuhnya Usman ibn Affan yang merupakan keluarga dekat Mu'awiyah. Peristiwa perang Shiffin puncak dari konflik politik yang terjadi antara Ali ibn Abi Thalib dan Mueawiyah. Perang ini pula yang menjadi cikal-bakal kemunculan sekte Khawarij.

Konflik dengan Mueawiyah ini dilatarbelakangi oleh pelbagai kebijakan Ali ibn Abi Thalib yang berusaha memulihkan stabilitas pemerintahan. Kebijakan untuk menempatkan Muawiyah di Syams terang-terang ditolak Muawiyah yang berimplikasi pada keengganannya membaiat Ali ibn Abi Thalib sebagai khalifah. Di samping itu, pemecatan gubernur-gubernur yang diangkat Uthman ibn Affan sekaligus menarik kembali tanah negara yang telah dibagikan kepada kerabatnya telah menempatkan kekhalifahannya pada posisi yang tidak strategis dan rentan terhadap berbagai pemberontakan. Rentetan kekecewaan Muawiyah ini mendorongnya untuk memisahkan diri dengan pemerintahan Ali ibn Abi Thalib, kemudian mendeklarasikan pemerintahan tandingan di Damaskus. Mu'awiyah mulai menyebarkan isu-isu politis, dengan menuduh Ali ibn Abi Thalib sebagai aktor di balik pembunuhan Usman ibn Affan. Dia juga menyeru penduduk Damaskus untuk mengkudeta pemerintahan sekaligus mempropagandakan revolusi.

Konstelasi politik antara Ali ibn Abi Thalib dan Muawiyah ini memuncak dengan pecahnya perang Shiffin. Dalam pertempuran yang terjadi antara kedua golongan tersebut, tentara Ali dapat mendesak tentara Muawiyah. Dalam kondisi terdesak Amr ibn al-Ash yang dikenal sebagai politikus ulung dan menjadi tangan kanan Mu'awiyah, meminta gencatan senjata dengan mengangkat mushaf Alqur'an ke atas. Qurra' yang ada di pihak Ali ibn Abi Thalib mendesak supaya menerima tawaran perdamaian tersebut. Permasalahan ini membuat Ali ibn Abi Thalib berada dalam posisi dilematis. Dia memberikan tawaran, apakah mereka mau mentaatinya dan melanjutkan peperangan ataukah membangkang. Sebagian dari pasukan Ali ibn Abi Thalib menghendaki agar perang dilanjutkan, sedangkan sebagian besar lainnya yang menjadi cikal-bakal sekte Khawarij menghendaki proses attahkim. Solusi damai tersebut berujung pada peristiwa attahkim. Sebagai pengantara diangkat dua orang, yaitu Amr ibn Ash dari pihak Muawiyah dan Abu Musa al-Asy'ari dari pihak Ali ibn Abi Thalib. Dalam pertemuan mereka, keulungan politi Amr ibn al-Ash mengalahkan ketaqwaan Abu Musa al-Asy'ari.

Sejarah menggambarkan antara keduanya terdapat pemufakatan untuk menjatuhkan kedua 
pemuka yang bertentangan, Ali ibn Abi Thalib dan Mu'awiyah. Dalam tradisi Arab Abu Musa alAsy'ari, sebagai yang tertua harus terlebih dahulu berdiri mengumumkan putusan menjatuhkan kedua pemuka tersebut kepada khalayak. Namun, berlainan dengan kesepakatan yang terjadi dalam proses attahkim, Amr ibn Ash hanya mengumumkan penyetujuan penjatuhan Ali ibn Abi Thalib, sebagaimana telah diumumkan Abu Musa al-Asy'ari, tetapi menolak penjatuhan Mu'awiyah. Sikap Ali ibn Abi Thalib yang menerima tipu muslihat Amr ibn al-Ash untuk mengadakan attahkim, sungguh pun dalam keadaan terpaksa, bersikeras melakukan langkah attahkim. Namun, karena hasil proses attahkim tersebut tidak sesuai dengan harapan, mereka menolak hasilnya dan berpaling dari barisan Ali ibn Abi Thalib. Mereka berpendapat bahwa hal demikian tidak dapat diputuskan oleh arbitrase manusia. Melalui jargon la hukma illa Allah, mereka menyuarakan bahwa putusan hanya datang dari Allah swt, dengan kembali kepada hukum yang ada dalam al-Qur'an. Mereka memandang Ali ibn Abi Thalib, telah berbuat salah dan berbuat dosa besar, sehingga mereka harus keluar dari barisannya tidak disetujui oleh sebagian besar tentaranya (Purnama 2016).

Kemunculan Khawarij pada dasarnya dalam peristiwa attahkim murni bersifat politik. Pada masa Abdul Malik ibn Marwan aliran ini mendapat sentuhan teologis-keagamaan terutama kelompok Azariqah yang sangat genjar mengembangkan doktrin Khawarij sehingga terjadi pembauran antara politik dan agama sehingga agama disesuakan dengan kepentingan politik pada masa itu, termasuk peristiwa attahkim, mereka berhasil melegitimasi ayat la hukma illa-Allah dengan selera politik mereka. Secara khusus ciri-ciri perdebatan Khawarij yaitu; 1) Fasih dan lancar berbicara, serta menguasai metode penyajian. Kelompok ini berusaha mempelajari al-Qur'an dan Sunnah, serta memahami hadis dan tradisi Arab dengan tekun, penjelasan yang terang dan semangat yang tinggi; 2) Mereka menyenangi perdebatan dan diskusi tentang sya'ir dan ungkapanungkpan Arab. Perdebatan mereka diliputi fanatisme;p 3) Kaum Khawarij senantiasa berpengang pada makna lahir al-Qur'e an tanpa mau mengkaji maksud, tujuan, dan konteks nash (Zahrah 1996); 4) Mereka adalah orang-orang yang sangat takwa dan tekun dalam beribadah (at- Tasyaddud fi al- 'ibadah wa al-inhimakfi-ha); dan 5) Mereka termasuk orangorang yang ikhlas dalam kukuh dalam berakidah (al-ikhas li al-'aqidah) dan memiliki keberanian yang tidak lazim (asy-syaja'ah an- nadirah). Watak ini menjadikan mereka sering kali melakukan peperangan/membunuh untuk keyakinan dan akidahnya.

Aliran Khawarij yang saling bertentangan hal yang disebabkan banyaknya perbedaan pendapat di antara mereka, yang hanya kadang-kadang masalah sepele, dan masing-masing mempertahankan pendapatnya. Meskipun demikian perselisihan mereka jarang kali menimbulkan peperangan. Aliran khawarij yaitu; azariqah; najdah; shafriyyah; ajaridah; dan ibadhiyyah. Aliran-aliran khawarij yang dipandang keluar dari Islam, aliran-aliran yang pendapatnya sedikit pun tidak termasuk ajaran Islam serta bertentangan dengan al- Qur'an dan hadis Nabi yang mutawatir, dijelaskan bahwa mereka ada 
dua kelompok yang prinsip-prinsip ajarannya keluar dari ajaran Islam yaitu; yazidiyyah dan Maimuniyyah. Mazhab Khawarij telah tumbuh dan berkembang dengan cara yang keras dan ekstrim dalam memahami ajaran islam. Hal itu terutama disebabkan oleh keinginan mereka yang kuat agar kebaikan dapat terlaksakan baik oleh diri mereka sendiri maupun dengan mengajak orang lain untuk turut bersama mereka.

\section{KESIMPULAN}

Munculnya aliran dalam politik Islam dilatarbelakangi oleh kepentingan kelompok yang mengarah terjadinya perselisihan hingga terbunuh Khalifah Usman. Kelompok Sunni dimulai sejak berakhirnya pemerintahan al-Khulafa' al-Rasyidun dikenal juga dengan ahlalhadis wa al-sunnah, ahlal-haqq wa al-sunnah dan ahlal-haqq wa al-din wa al-jama'ah. Setelah berakhir masa khalifah yang empat tersebut, naiklah Mu`awiyah yang membangun Dinasti Bani Umaiyah. Namun, naiknya Mu`awiyah mendapat tantangan dari sebagian umat Islam yang mendukung Ali (Syi`ah) dan kelompok sempalan Khawarij. Akhirnya pada periode awal umat Islam terpecah menjadi tiga kelompok, yaitu mayoritas pendukung Mu`awiyah yang kemudian dikenal dengan jamaah (Sunni). Syi'ah pengikut yang setia kepada Ali bin Abi Thalib dan mazhab politik yang pertama lahir dalam islam, mazhab ini lahir akhir pada masa pemerintahan Ustman, kemudian tumbuh dan berkembang pada masa Ali, setiap kali Ali berhubungan dengan masyarakat, mereka semakin mengagumi bakat, kekuatan beragama, dan ilmunya. Karena itu, para propagandis syiah mereka mengeksploitasi kekaguman mereka terhadap Ali. Khawarij adalah orang-orang yang kecewa kepada Ali Bin Abi Thalib karena menerima arbitrase dari Muawiyah, Kemudian mereka keluar dari barisan Ali, dan menghukum kan La hukma illa Lillah.

\section{DAFTAR PUSTAKA}

Abdullah, Taufik, Ahmad Sukardja, Azyumardi Azra, Bahtiar Effendy, Budhi Munawar Rachman, M. Din Syamsuddin, Hendro Prasetyo, Ihsan Ali Fauzi, Johan Hendrik Meuleman, Komaruddin Hidayat, Nurcholish Madjid, M. Quraish Shihab, and Sudarnoto Abdul Hakim. 2005. Ensiklopedi Tematis Dunia Islam. Jakarta: PT. Ichtiar Baru Van Hoeve.

Abidin, Zainal. 2006. “Syi'ah Dan Sunni Dalam Perspektif Pemikiran Islam.” HUNAFA: Jurnal Studia Islamika 3(2):117-128.

Abidin, Zainal. 2012. Imamah Dan Implikasinya Dalam Kehidupan Sosial. Jakarta: Balitbang Kemenag RI.

Al-Nemr, Abdul Mun eiem. 1988. Sejarah Dan Dokumen-Dokumen Syiah. Jakarta: Yayasan Alumni Timur Tengah. 
Genealogi Aliran-Aliran ..... Arif Al Anang dan Ahmad Husein

Al Anang, Arif. 2019. "Sejarah Perkembangan Ilmu Pengetahuan Dalam Islam.” Fajar Historia: Jurnal Ilmu Sejarah Dan Pendidikan 3(2):98-108.

Dewi, Oki Setiana. 2016. "Syiah: Dari Kemunculannya Hingga Perkembanganya Di Indonesia." Jurnal Studi Al-Qur'an 12(2):217-37.

Dhofier, Zamakhsyari. 1994. Tradisi Pesantren. Jakarta: LP3ES.

Djazuli, Ahmad. 2003. Fiqh Siyasah. Jakarta: Prenada Media.

Fadli, Yusuf. 2018. "Pemikiran Politik Islam Klasik (Studi Awal Atas Perspektif Kalangan Sunni)." Journal of Government and Civil Society 2(1):89-106.

Herlina, Nina. 2020. Metode Sejarah Edisi Revisi 2020. Bandung: Satya Hsitorika.

Hitti, Phillip K. 2005. History of the Arabs (Cecep Lukman Hakim \& Dedi Slamet Riyadi). Jakarta: Serambi.

Nasution, Harun. 1972. Teologi Islam: Aliran-Aliran, Sejarah Analisa Dan Perbandingan. Jakarta: Universitas Indonesia Press.

Nasution, Harun. 1986. Teologi Islam Aliran-Aliran Sejarah Analisa Perbandingan. Jakarta: Universitas Indonesia Press.

Purnama, Fahmy Farid. 2016. "Khawarijisme: Pergulatan Politik Sektarian Dalam Bingkai Wacana Agama.” Al-A'raf: Jurnal Pemikiran Islam Dan Filsafat 13(2):213-32.

Rozak, Abdul, and Rosihon Anwar. 2001. Ilmu Kalam. Bandung: Pustaka Setia.

Syafiie, Inu Kencana. 1996. Al-Qur'an Dan Ilmu Politik. Jakarta: Rineka Cipta.

Zahrah, Muhammad Abu. 1996. Aliran Politik Dan Aqidah Dalam Islam. Jakarta: Logos Wacana Ilmu.

Zahrah, Muhammad Abu. 2005. Imam Syafi'i: Biografi Dan Pemikirannya Dalam Masalah Aqidah, Politik Dan Fiqh. Jakarta: Lentera Basritama.

Zamzami, Teungku Muhammad Daud. 2007. Pemikiran Ulama Dayah Aceh. Jakarta: Prenada Media. 